\title{
Sustainable Performance and Environmental Health in Brazil: How to Understand and Measure!
}

\author{
Márcio Ricardo Costa dos Santos \\ Universidade Federal Fluminense (ASPI/UFF) \\ Academia de Medicina Veterinária (AMVERJ) \\ Instituto Camboinhas Ambiental (ICA-Nit) \\ Brazil
}

\section{Introduction}

Living together of people in harmony with nature is fundamental both for social development and for improving the quality of life and must be evidenced primarily by professionals involved in agricultural and health sciences. However, since the beginning of colonization of Brazil our natural resources have been exploited as predatory, and just consider, as an example, the Atlantic forest, one of the most valuable ecosystems of Brazil, which currently has only $7.3 \%$ of their original coverage. Our settlers-users enjoyed nature with careless posture and it has been almost totally destroyed. So if undertaken by centuries, through the industrial revolution, and expanding biotechnology for agricultural production, it has been consolidated in diverse environmental problems. The existence of these problems, in all regions of the country, requires the development and deployment of environmental educational programs, important in attempting to reverse or minimize this framework, to become an odd question and impregnate the consciousness of ecologically correct on all levels of our society.

Applications of technologies innovations contribute always more for global development; from the economical, social and environmental point of view, to produce more with respect to the living beings, and they are becoming hard to observe. The enterprise productive activities demand attention for research and the application of environmental evaluation systems, before the magnifying of the use of biotechnology products, because of the gradual focus changing to the green chemistry, biopharmaceuticals and bioenergy. Certification and rastreability methods gain importance on this process, with the establishment of multiple or mutually exclusive objectives between the social agents. Among the possible alternatives to carry out assessments of socio-environmental performance of urban and rural activities, the use of ecological and social indicators of sustainability and health has been a method of choice. The indicators should be organized in impact assessment systems that may span increasing levels of complexity and goal requirements for the environmental health management (Santos \& Rodrigues, 2008; Santos, 2010). 


\section{How to understand}

\subsection{The goal of the Brazilian Agenda 21}

International and national commitments undertaken since 1992 at the United Nations Conference on Environment and Development (Eco-92), in Rio de Janeiro, already showed that environmental conservation and maintenance of health should walk together with the development model to be exercised thereafter, to generate prosperity. Challenges for the new century, we highlight the "Global Development Agenda and Sustainability - Agenda 21 " with empowerment and engagement organizations, facilitating access to information and financial resources, and defraying ongoing activities on the global aspects of specific impacts. The 175 nations attending the Conference Eco-92 approved and signed the Global Agenda 21 and undertook to comply with its terms. It represents the basis for the continuation of life on the planet and the construction of a new development model, capable of achieving social justice and promotes decent conditions of life for present and future generations, without aggression to the environment or depletion of available resources.

One has to prioritize education and health, with the creation of public policies, human and animal rights for sustainable development. There are challenges apply to a society, which must act on themes such as water and sanitation management, assessment of climate change, income generation, poverty eradication and environmental justice. The plan was prepared by all countries, in dialogues and negotiations which had the participation of representatives of all layers of society present at the event. These recommendations also can steer Agenda and establish ways to live better and with good living conditions for all; they are ideas and principles which aim to create a sustainable world. It was hoped that the participatory process of commitments, actions and goals, to transform the development on the basis of the principles of life (the recommendations of Agenda 21), were adopted before the 21st century, i.e. between Eco-92 and the end of the year 2000, what did not happen everywhere in the world.

The construction of the Brazilian Agenda 21, the Commission of Sustainable Development Policies and National Agenda 21 (CPDS) aimed to introduce the concept of sustainability, to qualify the potentialities and vulnerabilities in Brazil in the international framework. The Brazilian Agenda 21 was released on July $16^{\text {th }} 2002$, on the site (http://www.mma.gov.br/sitio/ index.php?ido=conteudo. monta\& \& idEstrutura $=6$ idConteudo $=908$ ) in which refers to its content and it is possible to realize the nature of the process of strategic planning and participatory, to be implemented in stages. It is a widerange approach to a product of consensus among the different sectors of Brazilian society. At launch, six thematic areas were covered and named: sustainable agriculture, sustainable cities, infrastructure and regional integration, management of natural resources, reducing social inequalities, and science and technology for sustainable development. All this material is published in two documents as a result of discussions throughout the national territory, namely: the result of the national consultation (http://www.mma.gov.br/estruturas/ agenda21//consulta2edicao. zip files) and the priority actions (http://www.mma.gov.br/ estruturas/agenda21/_ files/acoes2 edicao.zip).

The goal of the Brazilian Agenda 21 deals with the promotion of sustainable agriculture. It reveals the desire of society to enjoy healthier products, with high levels of food safety, environmental, and it involves the technological innovations of the productive sector, which 
provide new methods applicable to agriculture. The solutions considered "sustainable" often require specific ecosystems and ecological knowledge, the large-scale demand that, initially, a work of education and awareness to preserve natural resources with sustainable performance. However, there is a situation that does not change so rapidly in population without basic knowledge of environmental health and what prevails is just the pace of innovation. The strength of the innovative trends regarding the different types of innovation in the industry generates conflicts between food production and preservation of ecosystems. Regulatory modalities of these conflicts become decisive so that there is peace in the rural and urban food productive sector.

Let's consider for example the Atlantic forest, which is very low, very fragmented in its original area and has currently only about $102.000 \mathrm{~km}$ to house all kinds of living things and keeping them, including fed! It is the second most threatened biome in extinction of the world; it loses only virtually extinct forests of the island of Madagascar in the African coast. Even so, the Atlantic forest biome presents an estimate of shelter around 1.6 million species of animals, including insects. There are cataloged 261 species of mammals, of which seventy three that only exist there and nowhere else on the planet Earth, are endemic in this biome, against 353 species catalogued in the Amazon, while Amazon biome is four times larger than the original area occupied by the Atlantic forest. There are 600 species of birds, of which 181 also are endemic of this forest. There are 280 species of amphibians, and 253 of this are biome endemic species! Reptiles reach 200 species, of which sixty are endemic. It is estimated that the biome is home to more than twenty thousand species of plants, of which eight thousand are endemic. It is the richest world's forest in diversity of trees and can provide, as in the South of Bahia, up to 454 different species per hectare!

All these figures actually represent an enormous wealth of biological diversity; is a greatness, which causes all of us proud to be living creatures in the vast biodiversity of an important Brazilian biome. But there are about 120 million people who live in the area of the Atlantic forest, which means that the quality of life of approximately $70 \%$ of the Brazilian population depends on the preservation of the remnants of the Atlantic forest biome! In this forest is the abstraction of water that keeps the springs and sources and that regulates the flow of fountains, in addition to providing conditions for cities and society may have supply at all levels of environmental health: it consists in regulating the climate, temperature, humidity, precipitation processes promotes rainy region, ensures soil fertility, protects the slopes of hills, slopes and creates conditions for reproduction and perpetuation of wild and domestic species in the region. Anyway, it allows the existence of life!

\subsection{Sustainable performance a question of mentality}

To have a sustainable performance is a question of mentality and it means changing your habits for better and having a healthier life (Figure 1). The biggest challenge, according to the authors: the population will put into practice in their homes and also in their cars, with near zero cost, important actions searched. Some of the measures envisaged are: to use clean energy, refrigerators and cold lamps with certification, which consume less energy; dry clothes outdoors instead of using machines; clean and adjust the air-conditioning and heating; choose LCD televisions instead of plasma apparatus; turn off appliances from stand-by; save water, etc. In automobiles, the measures involve the owner to exchange regular engine oil, systematic verification and control of emissions, as well as maintaining 
the recommended pressure in the tires. In addition to these actions, the driver shall drive sparingly in speed, without abrupt maneuvers, and avoid unnecessary braking, which increase fuel consumption. To complete, scientists encourage attitudes of courtesy and partnership between citizens, and the use of a single vehicle by several known people to travel with the same goal and to the same places.

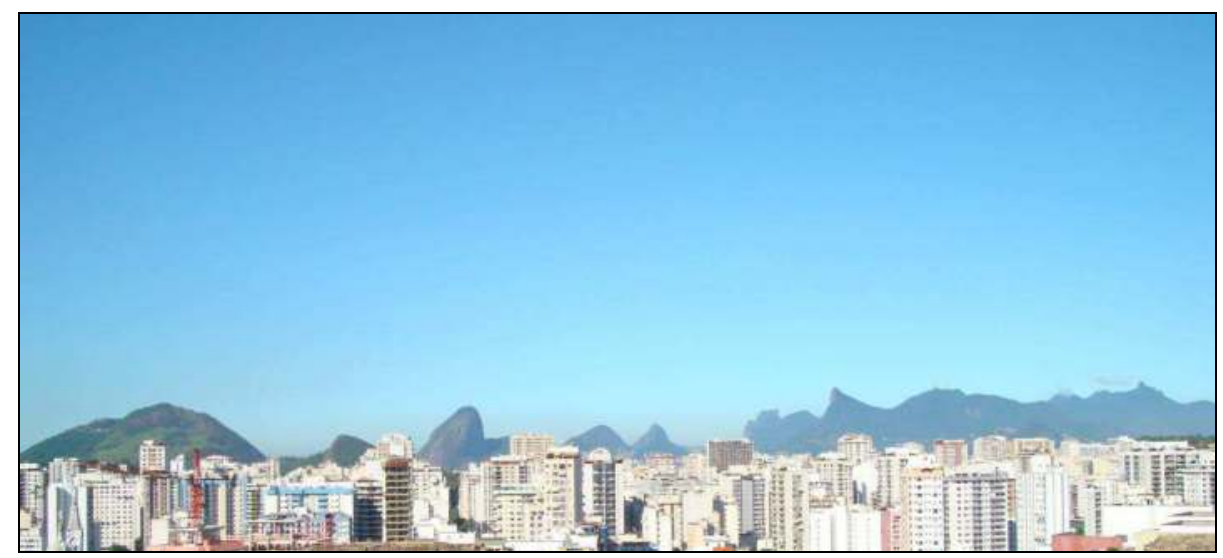

Fig. 1. A beautiful view from the top of Rio de Janeiro skyscrapers: how beautiful are the socio-environmental health and the sustainability down there?

For example, people need to think carefully that agriculture needs to adapt to the new rules of garbage treatment. Decree lays down rules for waste disposal and reutilization from the industry, including refrigerators, sugar mills and alcohol and packaging companies: The agricultural sector should adapt to new rules for the treatment and disposal of garbage. Decree No. 7.404, published on January 23rd 2010, regulates the National Solid Waste Policy and establishes the standards for selective collection and refund of the productive sector solid waste for reuse or other environmentally appropriate. The legislation includes, for example, the procedures for the manufacture of pet food from bovine bone and the use of biomass as residue of sugar cane, for energy production. One must comply with manufacturers, distributors and sellers of used packaging or other wastes, involving products such as pesticides, batteries, tires, lubricating oils, light bulbs and electronics. The determination is valid for companies which have concluded agreements with the public sector for the deployment of shared responsibility through product life cycle (sectored agreement).

The legislation also strengthens the recoil, and reusing packaging of agrochemicals and the treatment of products seized and waste produced in ports, airports and border procedures already provided for by law. "The Decree represents a breakthrough in the treatment of waste in the country and ensures the use of by-products and residues of animal and vegetable regulated industries by unique attention to livestock production sanity (Suasa)". The measure applies to the processing of plastic containers, cardboard and disposable plastic bottles; they now should be reused or recycled and can no longer be destined for the landfills (Figure 2). According to the Ministry of Agriculture the law establishes and reinforces the concepts of non-reporting, reutilization, recycling, reuse, treatment and 
energy recovery from waste discarded by the productive sector. The law also provides for the replacement of garbage dumps by landfill for waste, the creation of municipal plans, state and federal for waste management and encouraging cooperative funding lines, which should assist the selective collection and reverse logistics. The regulation requires that the procedure of urban collection at least separate recyclables and humid.

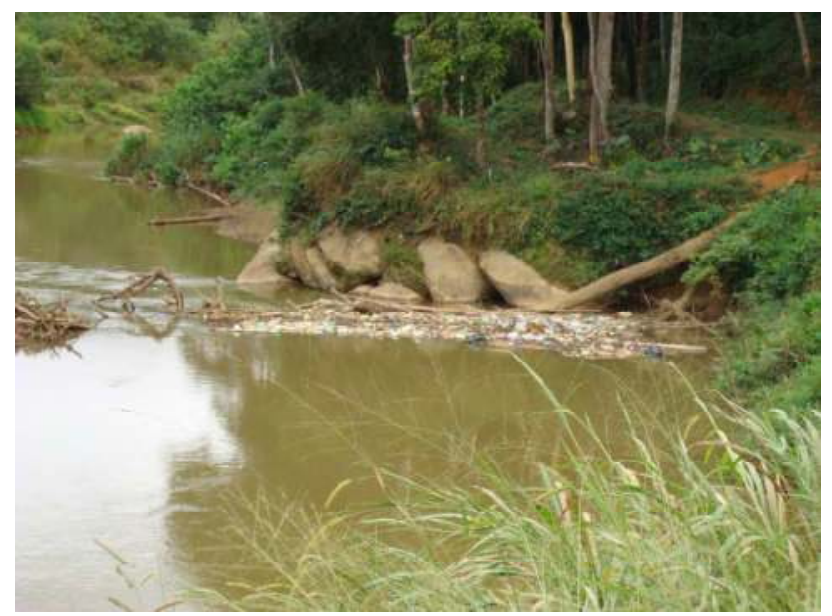

Fig. 2. Population depends on the preservation of the Atlantic forest biome remnants and disposable plastic bottles should not be destined for the rivers!

The International Organization for Standardization's (ISO) new guidelines are internationally accepted standards, on social responsibility for all organizations, public, private or third sector, and the World Society for the Protection of Animals (WSPA) celebrates the inclusion of animal welfare in the newly launched ISO Standard 26000. This published inclusion of animal welfare in ISO 26000 marks a historical first step, as it will encourage a large number of entities to acknowledge the importance of animal welfare while pursuing certification as per ISO standards. Their WSPA international programs manager believes that this is a landmark, because it states unequivocally that animal welfare matters to all. "Our actions impact animals in countless ways and accordingly, we have a responsibility to ensure their welfare is respected, be it as a company, school, municipality, church, university, ministry or in any other form we organize ourselves." The standard, although voluntary, is highly significant as it states what organizations need to do to operate in a socially responsible manner, stipulating that the welfare of animals used economically, or in any other way, must be taken into consideration.

Most notably, the text of ISO 26000 states that organizations should aim at: "respecting the welfare of animals, when affecting their lives and existence, including by providing decent conditions for keeping, breeding, producing, transporting and using animals." The standards also make specific mention of the physical and psychological wellbeing of animals in several chapters, not restricted to the section relating to the environment. The need to take animal welfare into consideration in an organization's business practices has also been integrated into actions governing ethical behavior, consumer issues and community involvement and development, specifically in wealth and income creation. 
The inclusion of animal welfare in these standards is a result of a very hard working from sustainable citizens, i.e. WSPA, together with Dutch consumers association and others, which has been presented in the working group discussing the development of ISO 26000. Discussions on ISO 26000 began in 2005 and the working group which ISO formed to develop the standard was the largest in the Swiss-based organization's history, involving around 400 experts from 99 countries. After an initial focus on corporate responsibility, it was decided to open the standard up to include all types of organizations. "So far, because animal welfare was not part of the ISO benchmark, organizations could claim to take their social responsibility seriously, despite overlooking the interests of the animals affected by their business practices," said WSPA's international programs manager. We all hope that other organizations responsible for issuing guidelines or standards - such as the IFC or OECD - will follow the ISO example, giving animal welfare its rightful place as a critical aspect of social responsibility. The ISO Working Group agreed that it made sense to include animal welfare as an element of social responsibility, because the specific issue of animal welfare is a relatively new subject in ISO standards. Bringing together so many experts from different stakeholder interests to debate this new standard has helped to ensure that the final consensus represents a depth and breadth of input on social responsibility as a whole.

\subsection{The role of health professionals - Veterinarians ${ }^{1}$}

Here comes the need for reflection on the role of the Doctors Veterinary Medicine, especially one that deals with the formation of new professionals and that has often taken a practice uncoupled from research and continued learning. The veterinarian who performs an educational work acquires its political potential in as much as it promotes technical skills, and values of the scientific information and it can involves students and producers in the process of professional development; it must generate a space for discussion, in search of solutions to the problems and the limiting situations, with paradigm shift to sustainable. It is important to consider that the interest groups have particular ways of understanding reality, of interpreting the alternatives and commit themselves with the proposals, but they must participate in decisions about what to put in place to better involvement and development of the profession: forming brains is more profitable and significant long-term than selling land, logic that reverses the flow of current use of technologies developed abroad and promotes intellectual property country for export. Universities and research centers or Brazilians institutes are fundamental to the development of technologies, innovation, quality assurance and environmental management, and also for finding alternatives which benefit populations in general.

The extension projects (Figures $3 \& 4$ ) are very important in this context, to act on the interface producer/production, processing and warehouse/distribution/social development. The extension teaches and guides the population in the deployment of development projects, being a channel to lead the technology involved in the production chain of those who are outside of research cores. Prospects and guidelines for the sustainable development should be addressing the implementation of measures integrating society with these institutions; that also spreads the results of work undertaken in obtaining

\footnotetext{
${ }^{1}$ In honor of the World Veterinary Year - 2011; the 101st birthday of the first Veterinary School creation in Rio de Janeiro - Brazil, and the $250^{\text {th }}$ birthday of the first Veterinary School creation in Lyon - France (la première École Vétérinaire au monde)!
} 


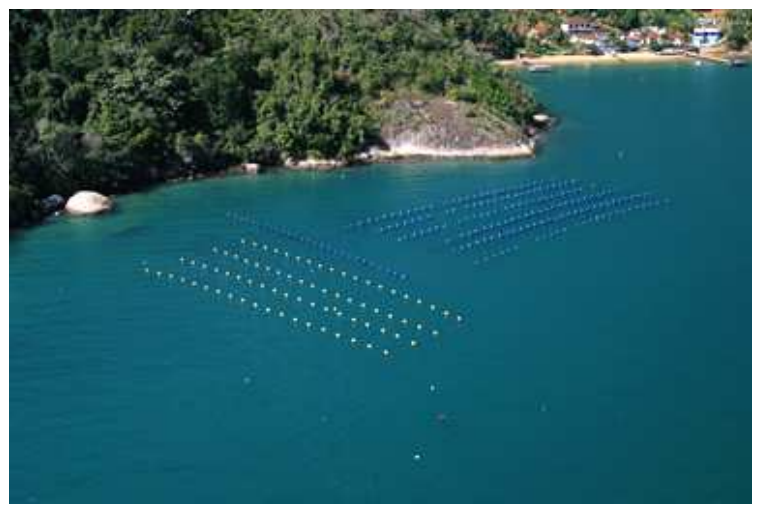

Fig. 3. Marine farms in Angra dos Reis, RJ: cultivation technologies in hatcheries.

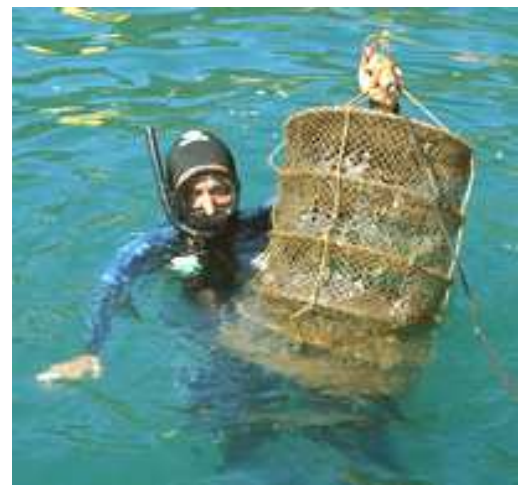

Fig. 4. Students visiting mollusks cultivation in hatcheries at the marine farms.

information about the economical situation, social and environmental area and promoting the necessary interventions, both through technical assistance and policy decisions inherent promotion of development, based on sustainable management of technological innovation.

We believe that the veterinarian has a key role in raising awareness and regulation of this area and in these involved industries, including the agribusiness. For example, only the correct usage of pastures in degraded areas in Brazil could avoid the emission of 80 millions tons of $\mathrm{CO}_{2}$ in equivalence a year. This value is bigger than the Brazilian industrial emissions that according to the latest research in 2005, was 78 millions of tons in equivalence. The numbers were calculated by Icone, a partner of Getulio Vargas Foundation (FGV) in a launched report about the emissions in the agricultural sector in 2010 (Beef Point). The need of the veterinarian in rural areas is also growing, not only as a health professional or in the control of epidemics, but mainly for the environment. This concern with awareness encompasses all areas occupied by these workers, necessitating even social, cultural, political and economic interaction.

However, many newly trained, professionals do not consider themselves qualified with the requirement of market to offer creative ideas on how to assist and practicing sustainability 
in its profession; and such due to the importance of a trader in so many areas, their training is fundamental to it can express all their capacity. According to our survey, the opinions of veterinarians are quite different. Only a small portion defends that veterinarians can operate easily on a multidisciplinary and only means baggage graduation, while most think that the same learn more about education and social responsibility, not only in relation to the issue of sustainability, but also by the degree of relevance which this professional has in public health and health animal. This indicates that there is a need for greater attention to the collective health, taking into consideration social, cultural and economical aspects and will have a higher degree of commitment to the health of the population.

The lack of interaction between veterinary medicine preventive and public health with the humanities and social sciences is a reflection of the lack of interaction of courses with other areas of knowledge. Veterinary medicine in the 1980s was ranked as one of agronomical sciences in Brazil and since then, conversely, was being simplified in its most basic principles that could express the medical activity with intervention in clinic, in human and animal health. Similarly, studies concerning the ecology and the environment, that in whole form a single, indivisible biosphere and impossible to be understood through pieces were underestimated. This absence of a systemic and holistic look led to the formation of professionals more directed to the production of animal origin foodstuffs and their derivatives, to take account of the accelerated process of industrialization of western countries and to the dictates of an uneducated and rambling consumer market, which prioritizes the immediacy in detriment of the ecosystems on which was created. Something was broken, complex production systems, adapting social, cultural and environmental areas were disrupted before being examined as to their sustainable efficiency, and in many cases in which progress has brought misery, we didn't know how to revert any more and neither are we able to conjure up something that may replace it. This is the true complexity! We have a sequence of events which escape our cognitive capacity, about which we talk and understand what we've done and what we can do to avoid aggravating more distortions generated by our ignorance, immediacy or disengaging with nature and the future of us all.

In the new century are expected from health professionals, educators and agronomical sciences, full of knowledge of all the intricacies surrounding the work, performed worldwide with Agenda 21, is either global, national, state or municipal, but that features the construction of a healthier world at present and that extends into the future, getting better for people and animals. Sustainable performance in veterinary medicine comprises a participatory process that can: a) provide awareness of involved veterinarians, with changes of attitudes in the quest for integration between the different sectors of society, in line with the principles of sustainability, to consolidate a culture of professional development and biotechnological innovation; b) apply to students, clients and other members of the community the full exercise of social responsibility, according to their professional competence; c) contribute to improving human relationship amongst themselves, with participants in society and with the animals, to exercise the ethics, the well-being and health habits, for personal hygiene and food; d) promote interactive practices, values and discuss with colleagues, students, clients and public participant, to teach new ways and opportunities for insertion into a quality market, with the adoption of appropriate technologies to environmental management, either in the agribusiness as a whole, whether in rural or urban activities too; e) generate new money in qualified and well-paid positions, through consultancies and expert services run by veterinarians involved with sustainable business management. 
A new methodological approach with the development of perception of environmentdependent health can be a key instrument for awareness and changing values and attitudes in rural and urban area. Educational work effectively targeted towards the human being, but that reaches the animals, the environment and meets the demand of processes to a Veterinary of the new millennium, in which the exercise of the profession and the production of food become a premise of sustainability. Health professionals can thus contribute to building a sustainable society, working in training multipliers in the various sectors of the communities where they operate and develop the perception of collective learning and knowledge of environmental reality of each of its ecosystems. In order to exercise awareness of society about the importance of the environment to health, for the production of safe food and for a sustainable future should obey this methodology: an educational mass process exercised in their daily deals with the capture of multipliers in different sectors of their communities, including veterinarians, in public services, private and civil society. The proposed method should result in the compromise of each citizen to perform simple activities and collective interest around improving the quality of the environment and food. It may involve orientation and practices that stimulate cognitive affective capacities, and psychomotor reading about the diversity and complexity of landscape. Environmental safety can meet the issue of agriculture with the analysis of environmental impacts caused and emphasize its importance to human existence in rural areas, including the urban population, with an emphasis on reflection on the issues of strengthening of family agriculture and agro ecology.

The evaluation of health education should assist in continual improvement of veterinary medical education on the health of the population related cultural menu and biotechnology innovation processes, with the establishment of conditions for continuity and permanence of sustainable populations as a result of improvements in environmental quality. The perception of the elements of the environment will be facilitated to the extent that we enter as part of nature, interacting with it as individuals and also in social groups. There is no need to restructure, but to innovate in the methodology, in order to meet demands for an educational process effectively, with contemporary calls like "Sustainable Business" to stimulate partnerships and implement projects. New diagnostic techniques, impact assessment and environmental management not only enable a thematic for agribusiness, but can also promote the execution of simple experiments that help the study of basic and significant issues such as the possession charge of pets in urban or rural environment, micro-organisms important in agro-environment and health impacts of risk by pesticides on aquatic organisms.

For example, fines for violating Canada's Health of Animals Act have more than doubled the Canadian Food Inspection Agency reports. In a statement, CFIA said the Government of Canada is cracking down on those who mistreat and improperly transport livestock with the first increase in fines in over ten years. Stressed animals are generally considered to be more susceptible to disease and infections, making humane treatment an important food safety consideration. Violators now will face fines of up to $\$ 10,000$, up from the previous maximum of $\$ 4,000$ for convictions under the Health of Animals Act (Food safety news / Meat Trade News). Veterinary professionals should continually work towards improving animal health and welfare by way of available tools, such as advocacy, scientific research and lobbying to enact appropriate legislation. It is the responsibility of humans to ensure animal welfare and include steps to achieve proper housing, nutrition, disease prevention, humane and responsible care and humane handling of animals. 


\section{How to measure}

\subsection{Original research papers and literature}

Independently of the agribusiness branch, the certification and rastreability methods gain importance on this process, with the establishment of multiple or mutually exclusive objectives between the social agents. The application of different scales of space and secular measures in the delimitation of the impacts, and the use of not standardized criteria for evaluations are some of the problems which many times contribute for the failure of the studies on environmental impact of new used technologies (Andrioli \& Tellarini, 2000).

Among the possible alternatives to carry out assessments of socio-environmental performance of agribusiness activities, the use of ecological and social indicators of sustainability has been a method of choice (Girardin et al., 1999; Bisset, 2000; Santos, 2006). The indicators should be organized in impact assessment systems that may span increasing levels of complexity and goal requirements for the environmental management (Rodrigues et al., 2006; Payraudeau et al., 2004).

The Brazilian Agricultural Research Agency (Embrapa - www.cnpma.embrapa.br/) has proposed a system for environmental impact assessment of agricultural technology innovations (Ambitec-Agro) for the appraisal of research projects and technology innovations in the institutional context of research and development (Monteiro \& Rodrigues, 2006; Rodrigues et al., 2006), and in attendance to a demand of the "InterAmerican Institute for Cooperation on Agriculture - Cooperative Program for the Agricultural Technological Development of the South Cone" (IICA - PROCISUR, 2006 www.procisur.org.uy). Another platform from the Ambitec-Agro has been proposed, integrating all environmental and social indicators, to implement the natural resources and biodiversity management in Uruguay, known as Responsible Production Project (Rodrigues \& Viñas, 2007).

A derived impact assessment system organized toward eco-certification of agribusiness activities was applied with excellent results to the environmental assessment practice of the aquaculture activities in Rio de Janeiro State and presented in May 2006 (Santos, 2006). Our original paper worked out a sustainability evaluation system of best sea scallops (pectens) production practices and its applications as a project appraisal for the technology innovation management methodology in the Pectens In vitro Fertilization Laboratory, to attend the Ilha Grande Bay Marine Farming Program from the Institute for Eco-Development of the Ilha Grande Bay in Rio de Janeiro State (Santos \& Zaganelli, 2007). The system comprises a set of weighing matrices organized for the integrated assessment of socio-environmental indicators, including modules focused on the environmental impact assessment of sea scallops production, or similar agribusiness activities, with a specific module for social impact assessment. Another similar platform has been described recently by the author, integrating all environmental and social indicators, to implement the natural resources, biodiversity management and productive enterprises at the Camboinhas region in Niterói, RJ, but is still being published; the study worked out a sustainability evaluation system with 32 socio-environmental health indicators for best production practices and its applications as a project appraisal for different urban and rural activities, with a specific module for health and social impact assessment. The calculated impact indices facilitate to making socio-environmentally sound decision and allow the delineation of recommendations for 
performance improvements, as well as selection of best cases for benchmarking purposes (Santos, 2010).

Keywords: sustainable performance, environmental health management, sustainability indicators, impact assessment.

\subsection{Research methods}

An impact assessment system organized toward eco-certification of agribusiness activities was presented in 2006 and applied with excellent results to the environmental assessment practice of the aquaculture activities in Rio de Janeiro State (Santos, 2006, Santos \& Zaganelli, 2007). This paper presents the practical impact assessment method for the adoption of technology innovations in the Pectens In vitro Fertilization Laboratory (FIV-Lab) from the Institute for Eco-Development of the Ilha Grande Bay (IEDBIG), at the Jacuacanga district, Angra dos Reis, Rio de Janeiro State, Brazil (Figure 5).

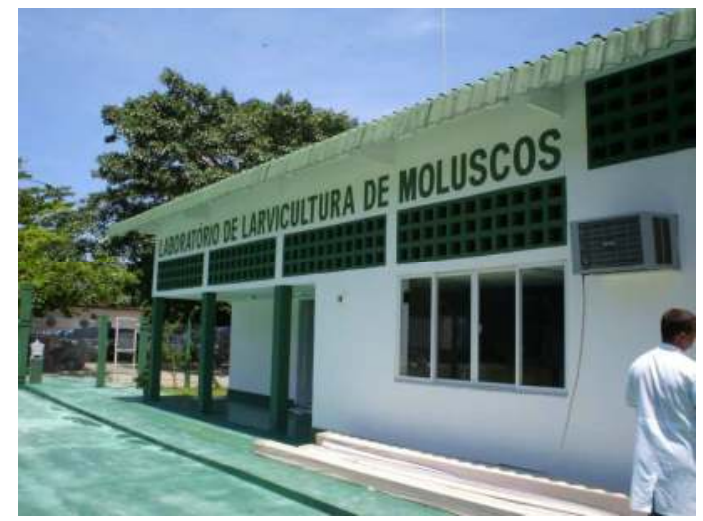

Fig. 5. The Larviculture and Oceanographic Research Laboratory from IEDBIG allow the reproduction control of fish spat, spawn and fry and research to increase aquaculture productivity in the region.

To fulfill the system framework requirements, focused on reproductive and productive enterprises, field visits and interviews supported by a structured questionnaire, with the laboratory executive director and farmers were carried out. The indicators related to soil and water quality were obtained by laboratory analysis at UFF, and the other related to historical and administrative knowledge of the director and farmers were obtained by local interviews.

The sustainability evaluation system of best pectens production practices (Best-SES) consists of a 24 integrated indicators set (Figure 6), spanning two dimensions namely landscape ecology and socio-environmental quality. These dimensions are integrated with seven essential aspects to encompass the IVF-Lab and the sea scallops, known as "Coquilles Saint Jacques" (Nodipecten nodosus, Linnaeus 1758) marine farms production, within the local environmental market settings. The indicators weighting matrices are constructed in a MSExcel® platform to translate variables and attributes into environmental impact indices, expressed graphically and related to a utility function of environmental performance 
benchmarks, derived from sensitivity and probability tests, case-by-case for each indicator. The Best-SES was formulated to evaluate the sustainability indicators, considering its benchmark compliance values, validated in contrasting situations representative of the establishments addressed spectrum, since the implantation of the technological innovations (2006) until the applied Best-SES (2008), according to the previous methodology presented by the authors (Rodrigues et al, 2006; Santos, 2006).

The qualitative research, type case study, followed a schedule of implementation, which encompassed the literature review, planning and data collection with the Company, obtaining Laboratory data, adequacy of the processing, evaluation if the model used by the establishment to comply with the precepts of sustainability, adequacy of proposals sought by the Institute to the template management, preparation of technical material for consultation and training. The samples of water and soil from surrounding marine farms and IVF-Lab were collected by the Institute's technicians and immediately sent for examination in reference laboratory. The laboratory results were presented to the author for verification and inclusion in spreadsheets. The evaluations were conducted in three stages, as the methodology used by Santos (2006).

The first stage referred to the activity process in the context of the establishment concerned, the definition of the impacts scope, the creation and characterization of indicators, according to the characteristics of the activity and the local environment, importance and weight of components and the range of occurrence in the establishment and their surroundings. A first visit to the laboratory and into two Marine Farms in the surroundings was then carried out.

The second consisted of survey and interview with the responsible Company, filling of the array weight of the system to generate partial indexes and aggregates of impact to graphic expression. In the second visit to the Institute took place a meeting with sea farmers and people connected to the activity promotion in Angra dos Reis; the Executive Director of the Institute was interviewed and set the period to be considered for the application of evaluation platform. The third step, immediately afterwards, was referring to the analysis and interpretation of these indexes. The verification of compliance, with an indication of alternatives for correction of non-compliance, in the forms of management and technologies used will be the subject of a work for hiring at the Institute, after presenting the report, to allow, so minimize the negative impacts, enhance the positive and contribute to sustainable local development.

In this study every aspect was composed of a set of indicators organized into automated weighting matrices, in which the components of indicators were evaluated with coefficients of variation, as personal knowledge of the person responsible for the activities in the laboratory. These indicators serve to recognize, in time, the environmental performance and environmental activities at the Institute; characterized the quality environmental management that must be deployed in the company analyzed. The procedure for evaluation of performance of the activity involved a survey with interview conducted by the user of the system - the author-and applied to the Director of the Institute, responsible for managing the IVF-Lab. The interview addressed the obtaining of the coefficients of variation of components, for each of the indicators of socio-environmental performance of the scallop culture, from March 2004, when it was deployed to technological innovation to IVF of Coquilles in the Lab, defined as the temporal cutoff for this evaluation. The impacts of the activities under the specific conditions of management in relation to the coefficient of 
variation of the component have been standardized as the values expressed in the following: for large increase in the component +3 , moderate increase in the +1 component, component unchanged 0 , moderate reduction in component -1 and large decrease in the component -3 . The Director chose the coefficients of variation of components, in particular reason activity and conditions for private management of the laboratory, according to this temporal Court.

The insertion of these coefficients of variation of the components of environmental indicators goes directly into arrays and sequentially in worksheets of ecological performance dimensions and socio-environmental Performance resulted in automatic expression of activity impact index weighted by scale factors of the occurrence and weight of components. The final results of the evaluation of the performance were expressed graphically in the "worksheet, activity, performance" presented at the end of this work, referring to the search results. Automatic arrays included also two weighting factors that relate to the scale of the event and to the weight of the component to the formation of the indicator. The scale of occurrence spells out the space in which the impact of the activity, depending on the particular situation of local application, and can be: punctual when the impact of the activity in the component is restricted to the area or enclosure in which it is occurring the change in the component; local, when the impact make it feel externally to this area, but confined to the limits of the productive unit or establishment; or in the surroundings when the impact reaches beyond the boundaries of the productive unit. The weighting factor of scale implied occurrence in multiplying the coefficient of variation of the performance component of the activity by a predetermined amount, as its scope, namely: punctual 1, local 2 and surroundings 5.

A second weighting factor included in the impact assessment matrices was the weight of the component to the formation of the performance indicator of the activity. The values of the weights of components expressed in the arrays can be changed by the user of the system, to better reflect specific situations evaluation, in which you want to emphasize some of the components, provided that the total weight of the components for a given indicator is equal to the unit $(+/-1)$. The indicators considered in whole defined the overall Performance of the activity, which involved the weighting of the importance of the indicator and the relative weights to the indicators. The composition of this index involves new weighting of the importance of indicators, and the relative weights to the indicators can be changed by the user of the system, provided that the total is equal to the unit (1). With this set of weighting factors, standardized scale in the system varied between -15 and +15 , standardized for all indicators individually and for the overall performance of the activity.

The survey used a set of spreadsheets, in MS-Excel, platform that integrated twenty-four indicators of performance for the scallops' productive economic activity at the IEDBIG. A total of 125 components, who understood the variables checked in accordance with their respective weightings amendment. These indicators were grouped into seven aspects and two dimensions, namely: environmental performance and socio-environmental Performance. The indicators were constructed in weighting matrices, in which quantitative data, obtained in the laboratory, were automatically transformed into impact indices, expressed graphically. Should be taken into consideration and emphasized that the report of the results obtained is directed to the producer, where the Director of the Institute, primarily with the indication of management strategies to minimize undesirable impacts and maximize those that contribute to the sustainable performance of the activities in the 
company, in the lab and surrounding marine farms. Finally, the making of report for the company, article for presentation in scientific events, and publications in specialized journals.

The base system of eco-certification of rural activities, used in this study, was described by Rodrigues et al. (2006) and presented a final worksheet with the results of each aspect studied, after the evaluation of the coefficients of variation for the components of social and environmental impact indicators and the calculation of their weighting in indexes arrays. All indicators were described and the results presented in graphics originating in their spreadsheets with the weighting tables, some of which are entered in this in the book. The results concerning the impact indices for each aspect were automatically expressed graphically in the performance of the activity sheet. Was assessed a set of twenty-fourenvironmental performance indicators, pectinicultura activity in the IVF Lab and Larvicultura of Scallops, which encompassed a total of 125 components, with verified variables according to their respective weightings amendment, on the dimensions of the ecological and environmental performance, bringing together the 24 arrays of weighting of indicators discussed.

\begin{tabular}{l} 
Socio-environmental Performance Impacts: \\
\hline \\
\hline \\
\hline \\
Employmer Respect \\
Revenue \\
Health \\
Management and Administration
\end{tabular}

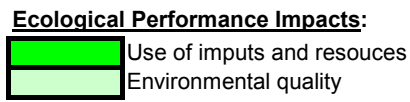

Fig. 6. Socio-environmental health quality and landscape ecology: indicators set for the ecocertification of agribusiness activities evaluation system. Data based on Santos (2006).

\subsection{Results}

The system's spreadsheets automatically calculated impact indices, in a scale ranging between \pm 15 , for 24 indicators from seven essential aspects, were as follows: Use of Inputs and Resources (-2.09), Environmental Quality (3.54), Costumer Respect (5.05), Employment (4.40), Revenue (2.17), Health (3.63), and Management and Administration (1.02). The general socio-environmental performance index (5.04) for the pectens production activities indicated an important contribution of technological innovations for the sustainability of Pectens FIV-Lab production. These results (Figure 7) show the good performance of the proposed system for the evaluation of technology management, agribusiness activities, regional development, and for sustainability performance assessment for pectens production.

The author observed also some improvement related with the management and sustainability of the population who work and live around the Institute: the goal of combating poverty as its line of strategy within the context of its social responsibility, and its main objective to encourage cultivation of endangered species in marine farms, while preserving traditional fishing methods, promoted the creation of more marine farms and worked towards the principle of sustainability and autonomy for low-income fishermen communities based in the region. That means, for example, the reproduction control of fish spat, spawn and fry and research to increase aquaculture productivity. As a result, marine fauna and its biota are being preserved and managed by the technicians themselves, who 
improve their incomes with the cultivation of endangered species. In addition to giving a tenfold return on capital invested, marine-culture provides jobs and other collateral activities.

\begin{tabular}{|c|c|}
\hline 5.05 & Costumer Respect \\
\hline 4.40 & Employment \\
\hline 2.17 & Revenue \\
\hline 3.63 & Health \\
\hline 1.02 & Management and Administration \\
\hline
\end{tabular}

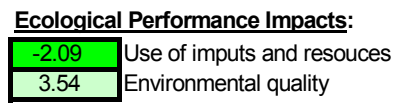

\begin{tabular}{|c|c|c|c|c|c|}
\hline Activity performance index & $\begin{array}{c}\text { Indicator } \\
\text { weight }\end{array}$ & $\begin{array}{l}\text { Perform } \\
\text { coeffic }\end{array}$ & & \multirow{2}{*}{\multicolumn{2}{|c|}{$\begin{array}{c}\text { General Socio-Environmental } \\
\text { Performance Index }\end{array}$}} \\
\hline \multirow{2}{*}{$\begin{array}{l}\text { Use agric. imputs \& resources } \\
\text { Agric. imputs \& raw material }\end{array}$} & 0.05 & 0.5 & & & \\
\hline & 0.05 & -3.0 & & & \\
\hline Use of energy & 0.05 & -12.0 & & & \\
\hline Atmosphere & 0.02 & 1.0 & & & \\
\hline Soil quality & 0.05 & 7.5 & & 15,00 & \\
\hline Water quality & 0.05 & -1.0 & $\ddot{c}$ & & \\
\hline \multirow{2}{*}{$\begin{array}{l}\text { Biodiversity } \\
\text { Environmental rescue }\end{array}$} & 0.05 & 6.0 & $\overline{\bar{\omega}}$ & & \\
\hline & 0.05 & 10.2 & 禹 & & \\
\hline $\begin{array}{l}\text { Environmental rescue } \\
\text { Product quality }\end{array}$ & 0.05 & 3.8 & 这 & & \\
\hline Productive ethics & 0.05 & 9.3 & ¿ & & \\
\hline Training program & 0.05 & 10.0 & $\Xi$ & & \\
\hline Loc.qualif. Employm.opport. & 0.02 & 6.7 & $\frac{5}{\pi}$ & & \\
\hline Offer employm. \& work cond. & 0.05 & 6.7 & E & & \\
\hline Employment quality & 0.05 & 10.8 & ō & & 5.04 \\
\hline Gen. income of the enterprise & 0.05 & 15.0 & む & & \\
\hline Divers. of Income generation & 0.025 & 7.5 & $\bar{\pi}$ & 0,00 & \\
\hline Property value & 0.025 & 9.8 & है & & \\
\hline \multirow{2}{*}{$\begin{array}{l}\text { Environm. \& personal health } \\
\text { Security \& professional health }\end{array}$} & 0.02 & 1.6 & $\stackrel{\oplus}{\varepsilon}$ & & \\
\hline & 0.02 & -1.5 & б & & \\
\hline $\begin{array}{l}\text { Security \& professional health } \\
\text { Feeding security }\end{array}$ & 0.05 & 9.6 & $\stackrel{1}{\Sigma}$ & & \\
\hline Manager \& dedication & 0.05 & 11.3 & $\Phi$ & & \\
\hline Business \& market conditions & 0.05 & 4.5 & 음 & & \\
\hline Waste \& water recycle cond. & 0.05 & -3.0 & O & & \\
\hline Institutional relationships & 0.02 & 7.5 & & & \\
\hline $\begin{array}{cc}\text { Weighted } \\
\text { average }\end{array}$ & $\begin{array}{l}\text { ivity } \\
\text { mance } \\
\text { dex }\end{array}$ & 5.04 & & $-15,00$ & \\
\hline
\end{tabular}

Fig. 7. Results obtained with the socio-environmental health and sustainability assessment for technology innovations at pectens production in Brazil: general socio-environmental indicators and its performance index for the activities.

\subsection{Discussion and conclusions}

While environmental conservation and social responsibility issues gain increasing importance in the development agendas at all institutional levels, it becomes necessary to select, adapt, transfer, and assess sustainable environmental management and best production practices (Barnthouse et al., 1998). Especial reference to this managerial movement is warranted when agribusiness activities are regarded, because of the spatial scale and bulk of natural and human resources encompassed worldwide by agriculture (Pimentel et al., 1992). In order to bring a practical reach to this sustainable development objective, society should value and recompense farmers and producers who adequately manage their environment and resources, both as an incentive towards sustainability and as repayment for environmental and social services rendered (Viglizzo et al., 2001). 
In effect, a multi-attribute EIA system for agribusiness activities' environmental management, integrating dimensions related to landscape ecology, environmental health quality, socio cultural values, economic values, and management values should be applied. It is currently under extensive field application, like this work, with contribution to the stepwise process of sustainable agricultural technology development and appraisal (Rodrigues \& Viñas, 2007; Santos, 2010).

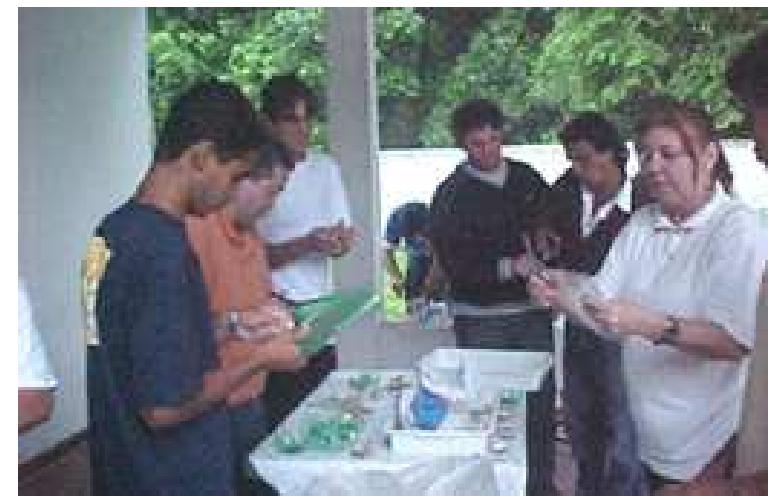

Fig. 8. More socio-environmental health quality: aquaculture, plastic lantern and handcraft products courses for the communities.

The IEDBIG established the goal of combating poverty as its line of strategy within the context of its social responsibility (Figure 8), and its main objective is to encourage raising endangered species in marine farms, while preserving traditional fishing methods. The Ilha Grande Bay Marine-Farming Program, known as POMAR, promotes the creation of marine farms and work towards the principle of sustainability and autonomy for low-income fishermen communities based in Angra dos Reis, State of Rio de Janeiro - Brazil (Santos \& Zaganelli, 2007). Considering the pectens production and the marine farms activities, 24 socio-environmental indicators were developed and the impact indices were automatically calculated by the system's spreadsheets. General performance index for the pectens reproduction activities indicated an important contribution of technological innovations for the sustainable production of the FIV-Lab. The employed method was considered as appropriate for evaluations of sustainability at this agribusiness activity, dealing with indicators as tools in order to identify possible risks for negative impacts. Those indicators include aspects beyond those commonly presented by environmental impact assessments (Girardin et al., 1999; Bisset, 2000, Rodrigues et al., 2006), and were capable to provide adequate management and sustainable development for the studied Organization. The present paper revised the impact assessment systems, discusses their application for the pectens production with technological innovation management, and aim to the conclusions:

a. The main contributions were to improve the understanding of producers and researchers alike, about the social and environmental implications of the adoption of agribusiness technology innovation, and to introduce socio-environmental impact assessments at an operational level, facilitating the grasp of interactions between technology adoption and the sustainable development of aquaculture. 
b. The acceptance of simpler assessment system is an important step toward more complex methods that require a stronger analytical basis and involve a more complex theoretical foundation.

c. The Best SES consists of a practical EIA system for technology innovations, ready for field application through interviews, with directed survey at the FIV-Lab, marine farms and manager responsible for the agribusiness activity, modified by the adoption of the studied technology.

d. The system relies on a computational platform readily available and easily applicable at low cost, and facilitates the storage and communication of information regarding environmental impacts.

e. The computational structure for the system is simple and transparent, unveiling to the user all operations performed with the data. Also, while fairly standardized relative to measurements, the system is malleable, allowing the user to adapt for specific use situations, by changing the weighing factors of indicators and components when appropriate.

This chapter presented and discussed an example of a practical impact assessment method to improve environmental health and we finalize saying: We do believe that in each living creature there is the desire to have a better life, of wealth and contribution, to be happy and make a difference! We can even doubt our ability to accomplish something grandiose and no matter what are the simplest, but it is true that we do. This potential is in every citizen, just decided consciously by such option and in various circumstances, whether at home, at work, whether in the society in which he lives. We all have the power to decide to live well, having not only a good day, but many great days and always there is the chance to change our attitudes and our world for the better. Always! It's never too late, and let's starts now to be a sustainable citizen.

\section{Acknowledgment}

The author thanks the ICA-Nit time for the together hard working; the Embrapa Researcher, Ecologist Geraldo S. Rodrigues for the contributions to this data and for advising his MBA Thesis; the President Director of IEDBIG, Engineer José L. Zaganelli for the partnership and previous cooperation. Mr. Alex Canella for the English revision and the InTech Publishing Process Manager for the attention and cooperation. This paper was approved by the Veterinary Medicine Academy from Rio de Janeiro State (AMVERJ), Brazil.

\section{References}

Andrioli, M \& Tellarini, V. 2000. Farm sustainability evaluation: methodology and practice. Agriculture, Ecosystems and Environment, Vol. 77, pp. 43-52.

Barnthouse, L; Biddinger, G; Cooper, W; Fava, J; Gillett, J; Holland, M \& Yosie, T (Ed).s)). 1998. Sustainable Environmental Management. Pellston: Society of Environmental Toxicology and Chemistry, Pellston Series Workshops. 102 p.

Bisset, R. 2000. Methods for environmental impact assessment: a selective survey with case studies, a methodology and terminology of sustainable assessment and its perspectives for rural planning. Agriculture, Ecosystems and Environment, Vol. 77, pp. 29-41. 
Girardin, P; Bockstaller, C \& van der Werf, H. 1999. Indicators: tools to evaluate the environmental impacts of farming systems. Journal of Sustainable Agriculture, Vol. 13, No. 4, pp. 5-21.

Monteiro, R.C \& Rodrigues, G.S. 2006. A system of integrated indicators for socialenvironmental assessment and eco-certification in agriculture - Ambitec-Agro. Journal of Technology Management and Innovation, Vol. 1, No. 3, pp. 47-59.

Payraudeau, S; Hayo, MG \& van der Werf, H. 2004.Environmental impact assessment for a farming region: a review of methods. Agriculture Ecosysistem and Environment, Vol. 107, pp. 1-19.

Pimentel, D; Stachow, U; Takacs, DA; Brubaker, HW; Dumas, AR; Meaney, JJ; O'Neil, JAS; Onsi, DE \& Corzilius, DB. 1992. Conserving biological diversity in agricultural / forestry systems. Bio Science, Vol. 42, pp. 354-362.

PROCISUR (PTR). 2006. In: Regional Technological Platform. Access on 02.01.2006, Available from < http://www.procisur.org.uy/online/sustentabilidad_inicial.asp >

Rodrigues, G.S \& Viñas, A.M. 2007. An environmental impact assessment system for responsible rural production in Uruguay. Journal of Technology Management and Innovation, Vol. 2, No. 1, pp. 42-54.

Rodrigues, G.S; Buschinelli, C.C.A; Rodrigues, I.A; Monteiro, R.C \& Viglizzo, E. 2006. Sistema base para eco-certificação de atividades rurais. Jaguariúna: Embrapa Meio Ambiente, In: Boletim de Pesquisa e Desenvolvimento 37. 40 p. Access on 04.28.2008, Available from: <http://www.cnpma.embrapa.br/public pdf21.php3?tipo=boEid=75 >).

Santos, M.R.C. 2006. Gestão da Inovação Tecnológica e do Desempenho Sustentável das Atividades em Laboratório de Fecundação In vitro e Larvicultura de Vieiras (Nodipecten nodosus). Monografia (MBA em Gestão de Negócios Sustentáveis, Universidade Federal Fluminense-Latec, Niterói: 2006). 95p.

Santos, M.R.C \& Zaganelli, J.L. 2007. Socio-environmental and sustainability assessment for regional development in Angra dos Reis, RJ - Brazil. In: Book of Abstracts. p.83. Access on 04.29.2008, Available from: <http://www.uni-tuebingen.de/deutschbrasilianisches-symposium/Symp2007-ed2.pdf >

Santos, M.R.C \& Rodrigues, G.S. 2008. Socio-environmental and sustainability assessment for technology innovations at pectens production in Brazil. Journal of Technology Management and Innovation, Vol. 03, No. 03, pp.123-128.

Santos, M.R.C. 2010. Desempenho Sustentável em Medicina Veterinária: como entender, medir e relatar. L.F. Livros Ed., ISBN 978-85-89137-15-7, Rio de Janeiro, 186 p.

Viglizzo, E.F; Lértora, F.A; Pordomingo, A.J; Bernardos, J; Roberto, Z.E \& Del Valle, H. 2001. Ecological lessons and applications from one century of low external-input farming in the pampas of Argentina. Agriculture, Ecosystems \& Environment, Vol. 81, pp. 65-81. 


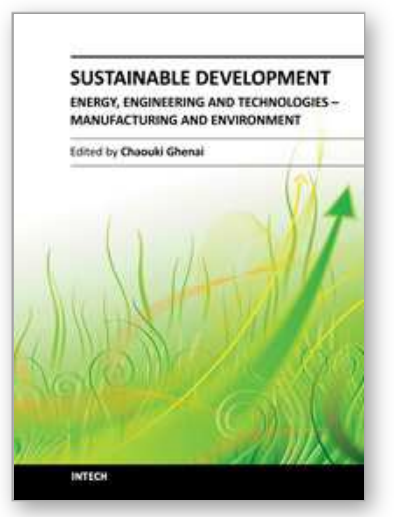

\author{
Sustainable Development - Energy, Engineering and Technologies \\ - Manufacturing and Environment \\ Edited by Prof. Chaouki Ghenai
}

ISBN 978-953-51-0165-9

Hard cover, 264 pages

Publisher InTech

Published online 29, February, 2012

Published in print edition February, 2012

The technological advancement of our civilization has created a consumer society expanding faster than the planet's resources allow, with our resource and energy needs rising exponentially in the past century. Securing the future of the human race will require an improved understanding of the environment as well as of technological solutions, mindsets and behaviors in line with modes of development that the ecosphere of our planet can support. Some experts see the only solution in a global deflation of the currently unsustainable exploitation of resources. However, sustainable development offers an approach that would be practical to fuse with the managerial strategies and assessment tools for policy and decision makers at the regional planning level. Environmentalists, architects, engineers, policy makers and economists will have to work together in order to ensure that planning and development can meet our society's present needs without compromising the security of future generations.

\title{
How to reference
}

In order to correctly reference this scholarly work, feel free to copy and paste the following:

Márcio Ricardo Costa dos Santos (2012). Sustainable Performance and Environmental Health in Brazil: How to Understand and Measure!, Sustainable Development - Energy, Engineering and Technologies - Manufacturing and Environment, Prof. Chaouki Ghenai (Ed.), ISBN: 978-953-51-0165-9, InTech, Available from: http://www.intechopen.com/books/sustainable-development-energy-engineering-and-technologiesmanufacturing-and-environment/sustainable-performance-and-environmental-health-in-brazil-

\section{INTECH}

open science | open minds

\section{InTech Europe}

University Campus STeP Ri

Slavka Krautzeka 83/A

51000 Rijeka, Croatia

Phone: +385 (51) 770447

Fax: +385 (51) 686166

www.intechopen.com

\section{InTech China}

Unit 405, Office Block, Hotel Equatorial Shanghai

No.65, Yan An Road (West), Shanghai, 200040, China

中国上海市延安西路 65 号上海国际贵都大饭店办公楼 405 单元

Phone: +86-21-62489820

Fax: $+86-21-62489821$ 
(C) 2012 The Author(s). Licensee IntechOpen. This is an open access article distributed under the terms of the Creative Commons Attribution 3.0 License, which permits unrestricted use, distribution, and reproduction in any medium, provided the original work is properly cited. 